\title{
SOSIALISASI DAN PELATIHAN PENYUSUNAN LAPORAN KEUANGAN UMKM DI DESA KERINJING KECAMATAN TANJUNG RAJA KABUPATEN OGAN ILIR SUMATERA SELATAN
}

\author{
Anton Indra Budiman'), Muhammad Ichsan Siregar ${ }^{2)}$, Ruth Samantha3), \\ Nur Khamisah"), Anisa Listya9), Trie Sartika Pratiwi6) \\ 1)23344556)Fakultas Ekonomi, Universitas Sriwijaya \\ Jln. Raya Palembang Prabumulih KM.32 Ogan Ilir, Sumatera Selatan \\ Email : antonbudiman483@gmail.com ${ }^{1)}$, ichsansiregar@fe.unsri.ac.id ${ }^{2}$, ruth samantha@fe.unsri.ac.id $^{3)}$, \\ nurkhamisah08@fe.unsri.ac.id ${ }^{4}$, listya anisa@fe.unsri.ac.id ${ }^{5}$, triesartika pertiwi@yahoo.com ${ }^{6}$ )
}

\begin{abstract}
Kegiatan Pengabdian Kepada Masyarakat ini bertujuan untuk memberikan pendampingan kepada masyarakat dan Usaha Mikro Kecil dan Menengah (UMKM) di desa Kerinjing agar mampu menyusun laporan keuangan sederhana agar para pegiat UMKM memahami manfaat yang dapat diperoleh sehingga dapat mengoptimalkan potensi pendapatan mereka. Adapun metode kegiatan ini dilakukan dengan memberikan penyuluhan dan sekaligus pendampingan secara langsung kepada UMKM di desa Kerinjing, Ogan Ilir. Hasil pengabdian masyarakat ini ditandai dengan antusias dan kemampuan peserta dalam menerima materi dan mampu melakukan praktek untuk mencatat inventarisasi aset, inventarisasi modal, inventarisasi hutang dan buku pemasukan dan pengeluaran. Hasil kegiatan ini sangat bermanfaat bagi UMKM di desa Kerinjing, Ogan Ilir.
\end{abstract}

Kata kunci : Laporan Keuangan, UMKM, inventarisasi aset, inventarisasi modal, inventarisasi hutang, buku pemasukan dan pengeluaran

\section{PENDAHULUAN}

Kabupaten Ogan ilir (OI) yang terletak di Sumatera Selatan memiliki enam kecamatan yang terdiri dari 227 desa dan 14 kelurahan. Sebelumnya, Kabupaten OI merupakan bagian dari Kabupaten Ogan Komering Ilir (OKI), akan tetapi sejak tahun 2003 Kabupaten OI telah memisahkan diri dan mendapatkan otonomi daerah secara penuh melalui Undang-Undang Nomor 37 tahun 2003 yang ditetapkan pada 18 Desember 2003 tentang Pembentukan Kabupaten OKU Timur, Kabupaten OKU Selatan dan Kabupaten Ogan Ilir di Provinsi Sumatra Selatan dan diresmikan oleh Menteri Dalam Negeri di Jakarta pada Tanggal 7 Januari 2004 bersama-sama dengan pembentukan 24 Kabupaten atau Kota di Indonesia. Desa Kerinjing merupakan salah satu dari 15 desa yang berada di Kecamatan tertua di Kabupaten OI, yaitu Kecamatan Tanjung Raja.

Sektor industri pengolahan yang mendominasi usaha masyarakat di Desa Kerinjing berdasarkan temuan pada observasi awal adalah Usaha Mikro Kecil Menengah (UMKM) seperti pembuatan pakaian (penjahit), pembuatan kerupuk, angkutan umum, dan warung sembako. Desa Kerinjing memiliki luas wilayah sebesar $\pm 3,00 \mathrm{Km} 2$ dengan akses jalan yang baik karena Desa ini berada di area sepanjang jalan Lintas Timur yang dilalui oleh banyak kendaraan. Dengan adanya akses jalan tol juga tidak akan mematikan UMKM yang berada di sepanjang jalan Lintas di Desa ini, karena dengan akses jalan yang mudah juga akan mempercepat waktu dan menghemat biaya distribusi produk-produk baik itu produk perkebunan dan pertanian, produk olahan serta jasa. Demografi penduduk Desa Kerinjing menunjukkan kelompok usia produktif (19-50 tahun) masih mendominasi dari total keseluruhan penduduknya, dengan jumlah penduduk berjenis kelamin wanita lebih banyak daripada jumlah penduduk pria. Oleh karena itu, dengan adanya campur tangan pemerintah dan civitas akademika melalui pelatihan dan pendampingan diharapkan UMKM di Desa Kerinjing dapat menggali potensi yang dimiliki agar dapat memaksimalkan pendapatan, yang apabila diterapkan secara konsisten dan berkelanjutan dalam jangka panjang akan menghasilkan kemakmuran masyarakatnya itu sendiri disertai dengan peningkatan pendapatan daerah. Pelaksana pada kegiatan pendampingan merupakan Dosen Fakultas Ekonomi Jurusan Akuntansi yang aktif dalam penelitian dan implementasi Ilmu 
Akuntansi. Pelaksanaan kegiatan ini juga didukung dengan fasilitas seperti modul yang mudah dipahami dan pelatihan yang tepat sasaran, sehingga kegiatan pendampingan ini diharapkan dapat berjalan maksimal.

Dengan pendampingan pelatihan yang baik mengenai penyusunan laporan keuangan sederhana akan menyebabkan UMKM memahami manfaat yang dapat diperoleh sehingga dapat mengoptimalkan potensi pendapatan mereka. Pelatihan dan pendampingan penyusunan laporan keuangan UMKM pada desa Kerinjing di rasa perlu karena selama ini banyak pegiat usaha yang kurang memahami manfaat dari sebuah laporan keuangan. Dengan demikian diharapkan setelah adalah pemahaman mengenai penyusunan laporan keuangan sederhana untuk UMKM. Kegiatan pengabdian ini diharapkan dapat memberikan manfaat sehingga UMKM dapat menyusun laporan keuangan sederhana yang baik dan benar dan dapat mengoptimalkan potensi pendapatan.

\section{STUDI PUSTAKA}

\subsection{Usaha Mikro Kecil dan Menengah (UMKM)}

Usaha Mikro Kecil dan Menengah (UMKM) atau sekarang yang dikenal juga dengan Entitas mikro, kecil, dan menengah (EMKM) adalah entitas tanpa akuntabilitas public yang signifikan, sebagaimana di definisikan dalam Standard Akuntansi Keuangan Entitas tanpa Akuntabilitas Publik (SAK ETAP), yang memenuhi definisi dan kriteria usaha mikro, kecil, dan menengah sebagaimana diatur dalam peraturan perundang-undangan yang berlaku di Indonesia, setidaknya selama 2 tahun berturut-turut (IAI, 2016).

\subsection{Laporan Keuangan}

Laporan keuangan merupakan hasil akhir dari proses atau kegiatan-kegiatan akuntansi yang dilakukan perusahaan yang disusun oleh manajemen perusahaan. Laporan keuangan disusun untuk mempertanggungjawabkan kegiatan peusahaan terhadap pemilik dan memberi informasi mengenai posisi keuangan perusahaan pada periode akuntansi yang berlaku. Laporan keuangan merupakan bentuk pandangan secara wajar mengenai posisi keuangan, kinerja dan arus kas perusahaan yang bermanfaat bagi sebagian besar kalangan pengguna laporan dalam rangka membuat keputusankeputusan ekonomi serta menunjukkan pertangggungjawaban (stewardship) manajemen atas penggunaan sumber-sumber daya yang dipercayakan kepada mereka (IAI, 2002).

Tujuan laporan keuangan adalah untuk menyediakan informasi posisi keuangan dan kinerja suatu entitas yang bermanfaat bagi sejumlah besar pengguna dalam pengambilan keputusan ekonomi oleh siapapun yang tidak dalam posisi dapat meminta laporan keuangan khusus untuk memenuhi kebutuhan informasi tersebut. Pengguna tersebut meliputi penyedia sumberdaya bagi entitas, seperti kreditor maupun investor. Dalam memenuhi tujuannya, laporan keuangan juga menunjukkan pertanggungjawaban manajemen atau sumber daya yang dipercayakan kepadanya.

Entitas menyusun laporan keuangan dengan menggunakan dasar akrual. Dalam dasar akrual, pospos diakui sebagai asset, liabilitas, ekuitas, penghasilan, dan beban ketika memenuhi definisi dan kriteria pengakuan untuk masing-masing pos-pos tersebut. Pada saat menyusun laporan keuangan, manajemen menggunakan SAK EMKM dalam membuat penilaian atas kemampuan entitas untuk melanjutkan usahanya dimasa depan (kelangsungan usaha). Entitas mempunyai kelangsungan usaha, kecuali jika manajemen bermaksud melikuidasi entitas tersebut atau menghentikan operasi atau tidak mempunyai alternatif realistis kecuali melakukan hal-hal tersebut. Jika entitas tidak menyusun laporan keuangan berdasarkan asumsi kelangsungan usaha, maka entitas mengungkapkan fakta mengapa entitas tidak mempunyai kelangsungan usaha.

\subsection{Laporan Keuangan UMKM}

Laporan keuangan minimum terdiri dari:

a. Laporan Posisi Keuangan Pada Akhir Periode;

b. Laporan Laba Rugi Selama Periode;

c. Catatan Atas Laporan Keuangan, yang Berisi Tambahan dan Rincian Pos-Pos tertentu yang Relevan.

Entitas Mengidentifikasi secara jelas setiap laporan keuangan dan catatan atas laporan keuangan.

Selain itu, entitas menunjukkan informasi berikut dengan jelas dan diulangi bilamana perlu untuk pemahaman informasi yang disajikan. Laporan keuangan yang harus disajikan oleh EMKM adalah (a) 
Laporan Posisi Keuangan, (b) Laporan Laba Rugi, dan (c). Catatan atas Laporan Keuangan

\subsubsection{Laporan Posisi Keuangan}

Laporan posisi keuangan entitas dapat mencakup pos-pos berikut:

a. Kas dan setara kas;

b. Piutang;

c. Persediaan;

d. Asset tetap;

e. Utang usaha;

f. Utang bank;

e. Ekuitas.

Entitas menyajikan pos dan bagian dari pos dalam laporan posisi keuangan jika penyajian tersebut relevan untuk memahami posisi keuangan entitas. SAK EMKM tidak menentukan format atau urutan terhadap pos-pos yang disajikan. Meskipun demikian, entitas dapat menyajikan pos-pos asset berdasarkan urutan likuiditas dan pos-pos liabilitas berdasarkan urutan jatuh tempo.

\subsubsection{Laporan Laba Rugi}

Laporan laba rugi entias dapat mencakup pos-pos sebagai berikut:

a. Pendapatan;

b. Beban keuangan;

c. Beban pajak.

Entitas menyajikan pos dan bagian dari pos dalam laporan laba rugi jika penyajian tersebut relevan untuk memahami kinerja keuangan entitas. Laporan laba rugi memasukkan semua penghasilan dan beban yang diakui dalam suatu periode, kecuali SAK EMKM mensyaratkan lain. SAK EMKM mengatur perlakuan atas dampakmkoreksi atas kesalahan dan perubahan kebijakan akuntansi yang disajikan sebagai penyesuaian retrospektif terhadap periode yang lalu dan bukan sebagai bagian dari laba atau rugi dalam periode terjadinya perubahan.

\subsubsection{Catatan atas laporan Keuangan}

Catatan atas laporan keuangan memuat:

a. Suatu pernyataan bahwa laporan keuangan telah disusun sesuai dengan SAK EMKM;

b. Ikhtisar kebijakan akuntansi;

c. Informasi tambahan dan rincian pos tertentu yang menjelaskan transaksi penting dan material sehingga bermanfaat bagi pengguna untuk memahami laporan keuangan.

Jenis informasi tambahan dan rincian yang disajikan bergantung pada jenis kegiatan usaha yang dilakukan oleh entitas. Catatan atas laporan keuangan disajikan secara sistematis sepanjang hal tersebut praktis. Setiap pos dalam laporan keuangan merujuk silang ke informasi terkait dalam catatan atas laporan keuangan.

\section{METHODS (METODE)}

Metode pelaksanaan pengabdian yang akan dilakukan dengan menggunakan metode ceramah, tutorial dan diskusi. Adapun sistematika pelaksanaan kegiatan pengabdian ini adalah sebagai berikut:

1. Langkah 1 (Metode Ceramah)

Peserta diberikan materi mengenai SAK UMKM dan Laporan Keuangan UMKM.

2. Langkah 2 (Metode Tutorial)

Peserta diberikan contoh ilustratif bagaimana melakukan penyusunan Laporan Keuangan sederhana untuk UMKM yang benar

3. Langkah 3 (Metode Diskusi)

Peserta pelatihan diberikan kesempatan untuk mendiskusikan permasalahan yang dihadapi berkaitan dengan penyusunan laporan keuangan untuk UMKM

\section{HASIL PENELITIAN}

Kegiatan pengabdian masyarakat mengenai "Sosialisasi dan Pelatihan Penyusunan Laporan 
Keuangan UMKM Di Desa Kerinjing Kecamatan Tanjung Raja Kabupaten Ogan Ilir Sumatera Selatan" telah dilaksanakan pada hari Kamis, 14 November 2019 dengan jumlah peserta perwakilan \pm 30 kelompok UMKM. Masyarakat Desa Kerinjing menyambut hangat kedatangan tim pengabdian Fakultas Ekonomi Universitas Sriwijaya. Selanjutnya, pelaksanaan pengabdian dibuka dengan sambutan oleh Kepala Desa Kerinjing, Faisal Kimi. Kepala Desa telah menyiapkan fasilitas tempat sebagai sarana kami untuk mengadakan pengabdian pada hari tersebut. Kemudian, kata sambutan juga diberikan oleh Bapak Drs. Burhanuddin, M.Acc, Ak selaku perwakilan dari dosen Fakultas Ekonomi Universitas Sriwijaya. Beliau menjelaskan mengenai tujuan dan manfaat dalam mengadakan pengabdian kepada masyarakat di Desa Kerinjing. Pengabdian ini juga rutin dilakukan tiap tahun mengingat adanya perjanjian kerjasama antara Fakultas Ekonomi Unsri dengan Desa Kerinjing untuk bersama-sama membina serta membangun tatanan ekonomi yang memiliki potensi untuk dikembangkan di Desa Kerinjing. Kegiatan pengabdian ini dilaksanakan seusai melakukan doa bersama untuk memohon kelancaran acara tersebut.

Pentingnya pengenalan tentang "Sosialisasi dan Pelatihan Penyusunan Laporan Keuangan UMKM" bertujuan untuk memberikan motivasi tentang pembukuan sederhana dalam menyusun laporan keuangan UMKM. Pelaksanaan kegiatan dilakukan dengan memberikan pemaparan dan penjelasan materi oleh perwakilan tim kami, Anisa Listya, SE, M.Si, dengan bantuan slide powerpoint untuk mempermudah menyampaikan bahan sosialisasi dengan pengaplikasian contoh. Pada saat pelaksanaan kegiatan kami juga membagikan modul kepada seluruh peserta "Sosialisasi dan Pelatihan Penyusunan Laporan Keuangan UMKM" yang hadir, di dalam modul tersebut telah dilampirkan secara jelas dan rinci mengenai tata cara penyusunan laporan keuangan sederhana untuk UMKM disertai dengan contoh kasus yang sering terjadi pada UMKM.

Permasalahan yang konon sering kali muncul sehingga menjadi menghambat penyampaian wawasan baru kepada peserta kegiatan pengadian di Desa Kerinjing adalah menumbuhkan tingkat kesadaran kepada masyarakat khususnya yang memiliki dan mengelola UMKM agar terbiasa menyiapkan laporan keuangan sederhana, sehingga nantinya diharapkan UMKM tersebut mampu bersaing dengan UMKM di kota besar bahkan bukan tidak mungkin mampu bersaing di mancanegara.

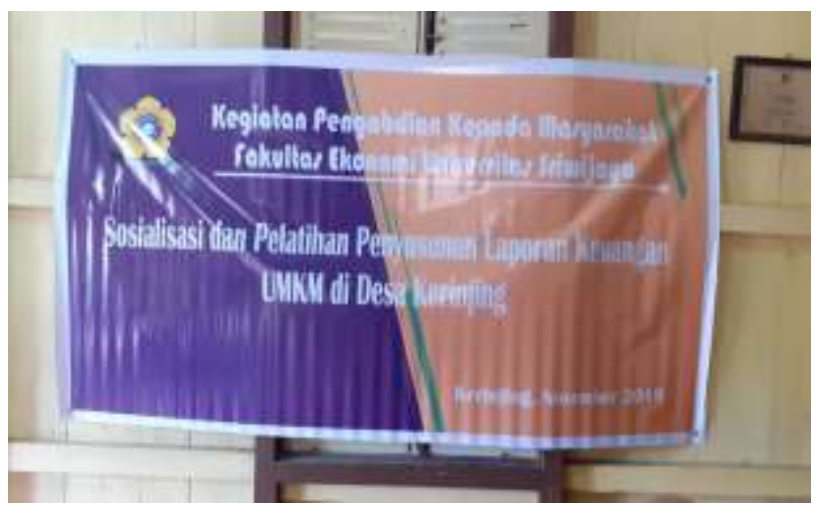

Gambar 1. Sosialisasi dan Pelatihan Penyusunan Laporan Keuangan UMKM

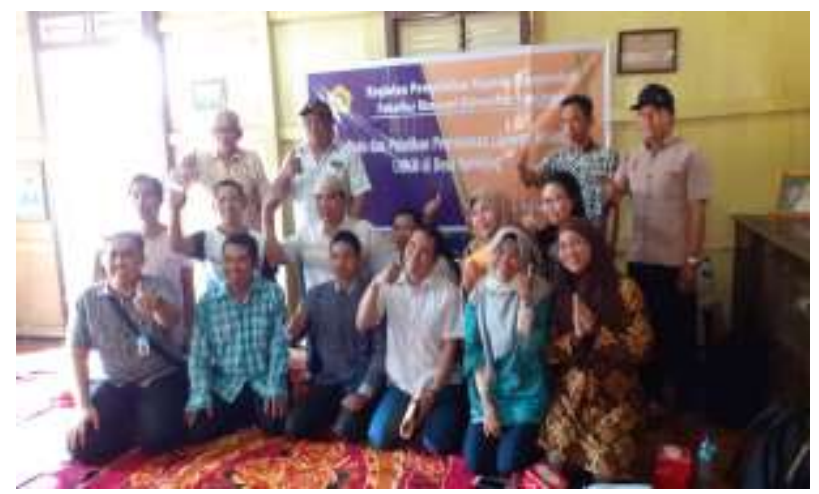

Gambar 2. Sosialisasi dan Pelatihan Penyusunan Laporan Keuangan UMKM 
Sesi diskusi menjadi penutup kegiatan pengabdian ini. Pada sesi ini peserta berhak bertanya dan berdiskusi dengan tim pengabdian kami berkaitan dengan materi yang disampaikan dalam paparan di sesi sebelumnya. Ada beberapa pertanyaan yang muncul berkaitan dengan materi tersebut, yang dirangkum sebagai berikut:

1. Bagaimana sistem pencatatan dalam informasi modal, apakah hanya mencatat informasi modal di awal atau di setiap transaksi penyetoran modal?

2. Mengapa setiap transaksi harus dicatat?

3. Apa saja yang termasuk di dalam komponen asset? Jawaban atas rangkuman pertanyaan tersebut adalah sebagai berikut:

1. Sistem pencatatan dalam informasi modal harus mencatat pergerakan modal setiap terjadi transaksi setoran atau penarikan modal, karena perubahan informasi modal dibutuhkan sebagai pertimbangan bagi pemilik usaha untuk melakukan ekspansi usaha atau tidak.

2. Transaksi adalah segala sesuatu yang berkaitan dengan kegiatan operasional perusahaan yang menggambarkan aktivitas keuangan perusahaan. Setiap transaksi tersebut harus dicatat dan dibukukan agar dapat menyusun laporan keuangan, sehingga informasi yang terdapat di laporan keuangan tersebut dapat digunakan sebagai digunakan sebagai pertimbangan dalam pengambilan keputusan usaha.

3. Aset adalah segala sesuatu yang dimiliki oleh kegiatan usaha baik yang berwujud maupun tidak berwujud yang digunakan dalam aktivitas usaha. Contoh asset dalam UMKM adalah uang kas, piutang, perlengkapan, peralatan, tempat usaha, persediaan barang dagang, kendaraan, tanah dan lainnya.

\section{KESIMPULAN}

Terdapat beberapa kesimpulan dari pengabdian ini yaitu sebagai berikut:

1. Kegiatan ini memberikan beberapa materi yang terkait dengan pengenalan laporan keuangan sederhana dan pengenalan tentang laporan keuangan UMKM.

2. Dengan adanya kegiatan pengabdian ini, masyarakat dapat memahami pentingnya peranan penyusunan laporan keuangan sederhana bagi UMKM di Desa Kerinjing, Kabupaten Ogan Ilir, Sumatera Selatan.

3. Dengan adanya kegiatan pengabdian tersebut, masyarakat di Desa Kerinjing dapat menyusun laporan keuangan sederhana bagi UMKM.

\section{ACKNOWLEDGMENTS (UCAPAN TERIMA KASIH)}

1. Fakultas Ekonomi Universitas Sriwijaya atas dana Pengabdian Kepada Masyarakat Tahun 2019 yang telah dianggarkan.

2. Kepala Desa Kota Kerinjing Bapak Faisal Kimi dan seluruh peserta kegiatan pengabdian kepada masyarakat Tahun 2019.

\section{DAFTAR PUSTAKA}

http://bappeda.sumselprov.go.id/userfiles/files/1458210388 1252754635.pdf diakses pada tanggal 20 Agustus 2019.

https://id.wikipedia.org/wiki/Tanjung Raja, Ogan Ilir diakses pada tanggal 18 Agustus 2019.

http://kectanjungraja.blogspot.com/2011/02/desa-kerinjing.html diakses pada tanggal 21 Agustus 2019

https://oganilirkab.bps.go.id/diakses pada tanggal 21 Agustus 2019 